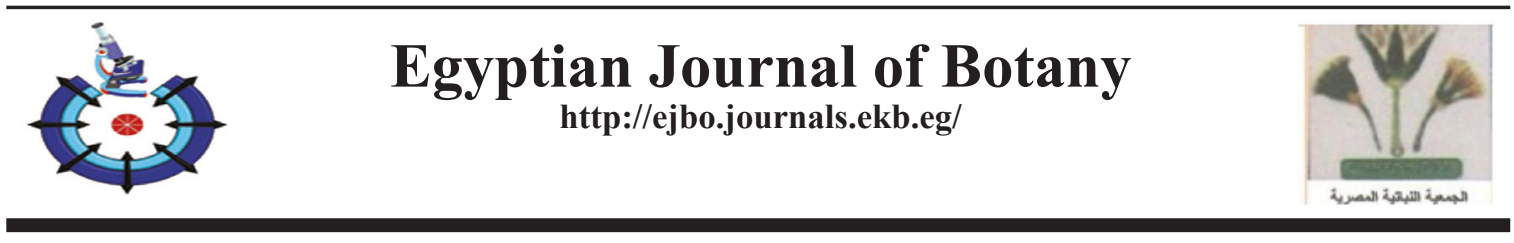

\title{
Exploration of Karyotype Differentiation in Cells of a Garlic Clone and its Derivative Filial Plants
}

Rasha Kamal Helmey Galal

Botany and Microbiology Department, Faculty of Science, Minia University, El-Minia, Egypt.

$\mathbf{T}$ HE COMMON garlic (Allium sativum L.) is vegetatively reproduced. Therefore, somatic mutations are the only source of variation and are often expressed as chromosomal changes. There is evidence for this hypothesis regarding satellite position on nucleolar chromosomes and asymmetry of karyotypes. The present work throws more light on the chromosome complement of a flowering clone (Egaseed 2). Using individual plants, some cytological metrics such as chromosome length, arm ratio, centromere position, relative length and karyotype formula were determined in cloves of a single plant and their derivative filial plants. One of the most important cytological parameters is the number and position of secondary constrictions and satellites on SAT-chromosomes. The results showed significant differences in karyotype parameters between cells of parental cloves and their F1 filial progeny. Moreover, asymmetrical chromosome measurements were displayed between sister cells of the same root. In addition, a dignified variation in number and position of SAT- chromosomes in the somatic complement of examined cells has been documented.

Keywords: Allium sativum, Chromosome measurements, Garlic, Karyotype, Satellite chromosomes.

\section{Introduction}

In many respects the species of the genus Allium have fascinating karyotype, they have medium to large sized chromosomes and polyploidy is common. For decades, chromosomes of most Allium species have been examined (Levan, 1932, 1935; Koul \& Gohil, 1970; Badr \& Ekington, 1977; Hamoud et al., 1990; Fritsch et al., 2001, 2010; Ata, 2005; Osman et al., 2007; Mukherjee \& Ray, 2012; Ramesh, 2015; Mahmoud et al., 2017) for their diversity in size, structure and number. Most species are diploid but the genus comprises many polyploid species and the diversity in the ploidy level ranged from $2 x$ to $10 x$. (Badr \& Elkington, 1977). The above examples and several other studies revealed patterns of karyotype evolution by chromosomal variations in the genus Allium (Badr \& Elkington, 1977; Peruzzi et al., 2009).
Chromosomes of garlic (Allium sativum L.) were described primerly by Khoshoo et al. (1960) and Battaglia (1963). A diploid number has been reported as $2 n=16$ with karyotypic formula of 6 metacentric, 4 submetacentric and 6 acrocentric chromosomes including four chromosomes with secondary constrictions and satellites (Bozzini \& De Luca, 1991). Karyological variations of garlic clones were reported for centromere location, chromosome length, and the number of satellite chromosomes. Some garlic plants showed tetraploidy with $4 n=32$, wherease diploid garlic $(2 \mathrm{n}=16)$ had two pairs of satellite chromosomes (Etoh, 1984, 1985; Hong et al., 2000; Osman et al., 2007; Mahmoud et al., 2017).

In garlic the satellite chromosomes were affected by structural abnormalities strikingly more than other chromosomes (Ata \& Osman, 2009; Anwar \& Ata, 2017). In terms of the

Corresponding author email: rasha.galal@mu.edu.eg

Received 16/6/ 2020; Accepted 24/7/ 2020

DOI: $10.21608 /$ ejbo.2020.32379.1508

Edited by: Prof. Dr. Abdelfattah Badr, Faculty of Science, Helwan University, Cairo, Egypt.

(C)2020 National Information and Documentation Center (NIDOC) 
number of SAT-chromosomes three different karyotypes were distinguished (Sato et al., 1980). Most of the clones examined had three or four secondary constricted chromosomes and only one had two of these in the metaphase complement. The longer pair of the SAT-chromosomes had smaller satellites than the shorter pair (Mahmoud et al., 2017). It has been noticed that, size of the achromatic secondary constricted regions varied between the different individual chromosomes of the same cells. Etoh (1984) demonstrated two pairs of SAT-chromosomes in garlic with big satellites. Therefore, the present work deals with the chromosomal variations recorded within garlic clone using individual roots. The study was extended to compare between karyotypes of cells from three bulbs of the same clone, two parent cloves derived from each bulb in addition to comparison between cells of parents and their filial plants. Furthermore, the cytogenetic characteristic differences between individual cells of the same root were scored.

\section{Materials and Methods}

\section{Materials}

Bulbs of Egyptian garlic clone (Egaseed 2) were kindly provided by the Horticulture Department, Faculty of Agriculture, Minia University

\section{Mitotic preparations and karyotype analysis}

Preparations of mitotic chromosomes and karyotype analysis were carried out in cells of roots of six cloves (cloves have been considered as clones by which they produced from a vegetative reproduction). Cloves are derived from three bulbs (two cloves from each bulb) and their vegetative reproducible offspring were studied . Root tips of $1-2 \mathrm{~cm}$ were grown from cloves, collected and pre-treated in $0.05 \%$ colchicine at room temperature for three hours and immediately fixed with Farmer's fixative solution (absolute Ethyl alcohol and Glacial acetic acid $3: 1 \mathrm{v} / \mathrm{v}$ ) for $24 \mathrm{hrs}$ and stored in $70 \%$ ethanol at $4^{\circ} \mathrm{C}$ until use. For cytological examinations, roots were hydrolyzed in $1 \mathrm{~N} \mathrm{HCl}$ at $60^{\circ} \mathrm{C}$ for six minutes then transferred to $70 \%$ ethanol. Acetocarmine-squashed preparations were made from the root tips and stained metaphase plates with well- chromosome spreads were selected for chromosome measurements. In addition, number and position of the secondary constrictions and the length of satellites were recorded. Good metaphase spreads were photographed microscopically using CCD camera (Olympus C-4040).

Chromosome measurements were recorded using the software KaryoType (Altınordu et al., 2016). The primary function of the software is to allow efficient measurements of chromosomes and micro-photographic karyotype analysis. KaryoType is also capable of measuring karyotype asymmetry indices such as CVCI and AsK and can recognize chromosome homologous based on chromosome length and arm ratio automatically or manually as described by Altınordu et al. (2016). The Karyotype measured metrics include chromosome length (CL), arm ratio (AR), centromeric index (CI), relative length (RL) and karyotype formula where chromosomes were arranged according to their total length. Karyotype parameters in addition to coefficient of variation of centromeric index (CVCI), karyotype asymmetry index (AsK) were estimated as prsented in Table 1.

TABLE 1. Karyological parameters used to explore the karyotype of garlic cells.

\begin{tabular}{|c|c|c|}
\hline Karyological parameters & Abbreviation & Formula \\
\hline Short arm length & $\mathrm{S}$ & \\
\hline Long arm length & $\mathrm{L}$ & \\
\hline Basic chromosome number & $\mathrm{x}$ & \\
\hline Chromosome length & $\mathrm{CL}$ & $\mathrm{L}+\mathrm{S}$ \\
\hline Arm ratio & $\mathrm{AR}$ & $\mathrm{L} / \mathrm{S}$ \\
\hline Relative length of chromosome & RL\% & $(\mathrm{CL} / \Sigma \mathrm{CL}) \times 100$ \\
\hline Centromeric index & $\mathrm{CI} \%$ & $\mathrm{~S} /(\mathrm{L}+\mathrm{S})$ \\
\hline $\begin{array}{l}\text { Coefficient of variation of centromeric index (a } \\
\text { measure of centromere position heterogeneity in } \\
\text { the karyotype) }\end{array}$ & CVCI & $\begin{array}{l}\text { standard deviation }(\mathrm{sCI}) / \text { the mean } \\
\text { centromeric index }(\mathrm{x} \mathrm{CI}) \times 100\end{array}$ \\
\hline Index of karyotype asymmetry & AsK $\%$ & $\begin{array}{l}\text { Length of long arms in chromosome set/ } \\
\text { Total chromosome length in set } \times 100\end{array}$ \\
\hline
\end{tabular}

Egypt. J. Bot. 60 , No.3 (2020) 


\section{Statistical analysis}

To determine the significance of the differences between means of total chromosome length (CL) as well as between means of arm ratio (AR) in the individual cells, data were statistically analyzed using SPSS 16.0 program. Values of these parameters in three cells of each root and three roots of each clove were applied. Means were compared using LSD test at the $\mathrm{P}<0.05$ levels.

\section{Results}

Karyotype variation between sister cells of the same root

Almost all examined cells were approximately in the same stage of condensation and have a somatic complement of $2 n=16$ (Figs. 1, 2). Chromosome measurements of representative samples of three sister single cells (from the same root) are given in Table 2 and their karyotypes are illustrated in Fig. 1. Noticed difference has been observed in their karyotype formula as $(14 \mathrm{~m}+$ $2 \mathrm{sm})$ for cell No.1 and $(13 \mathrm{~m}+3 \mathrm{sm})$ for cells No.2 and No.3. Also positions of nucleolar constriction, number and size of satellites as well as the Coefficient of variation of the centromeric index (CVCI) and Index of karyotype asymmetry (AsK) parameters were obviously different between the examined sister cells from the same tissue (root tip). Hence, the corresponding karyograms constructed via these parameters were clearly different as shown in Fig. 1. For instance, cell 1 showed 2 SAT chromosomes (number 12 and 13) while satellite chromosomes of cell 2 were number 8, 12 and 14. Whereas, cell 3 showed a pair of SAT chromosomes (number 13 and 14). In sat chromosomes, variable achromatic regions in the space of constrictions were also clearly seen as shown in the photographs (cell 2) in Fig. 1.

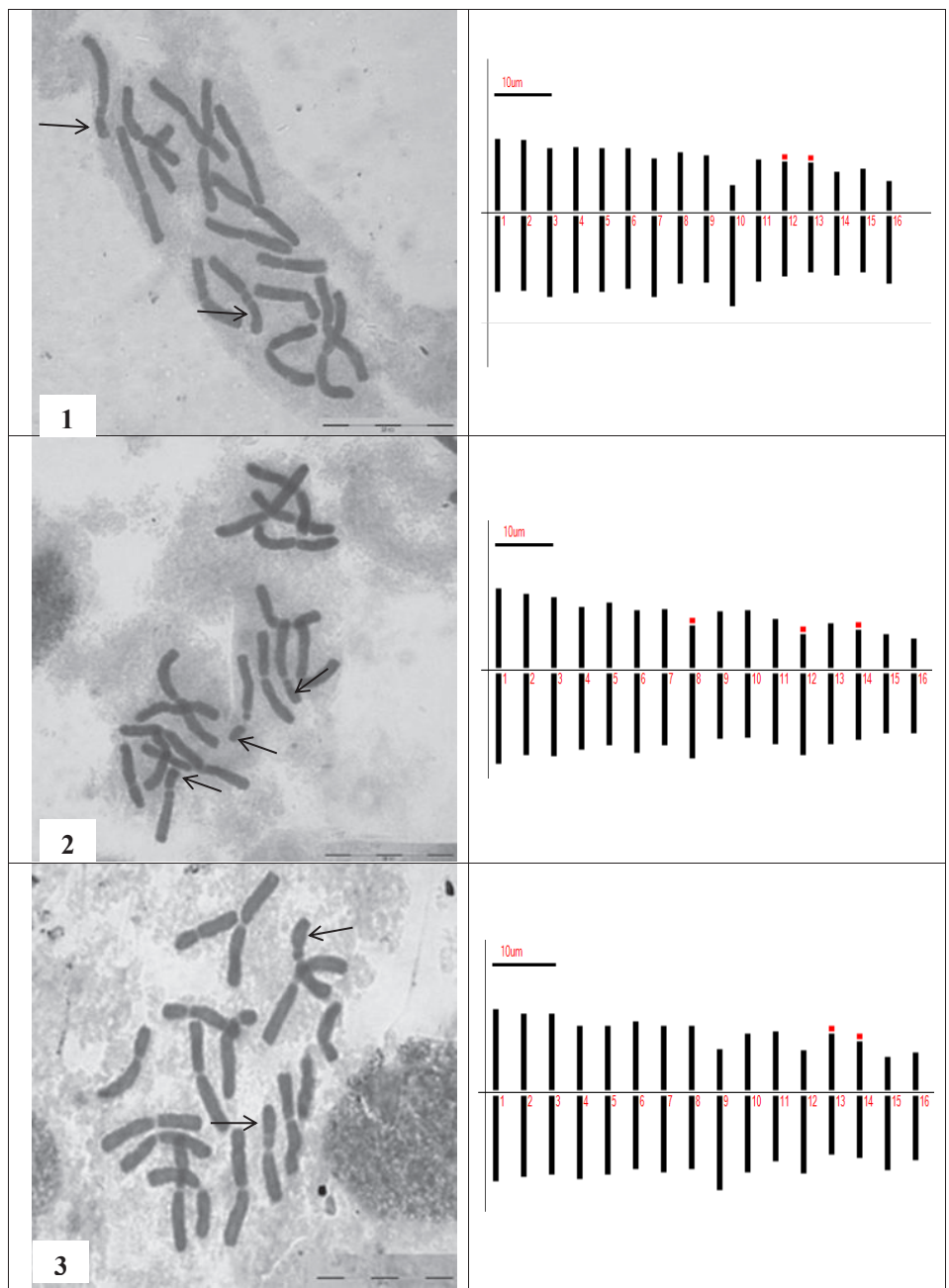

Fig. 1. Metaphase chromosomes of three sister cells of the same root and their representative karyotypes [Arrows for SAT- chromosomes]. 


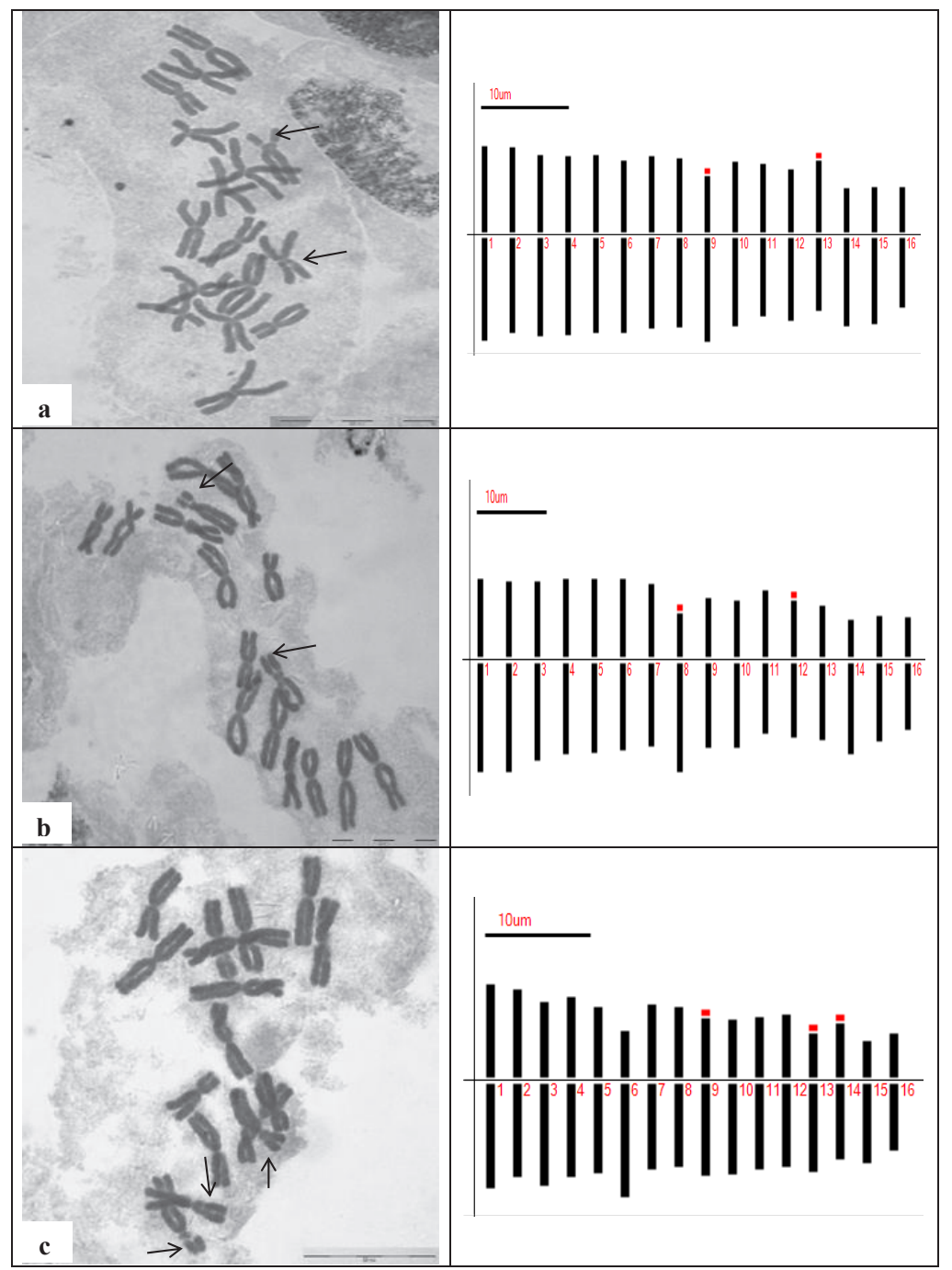

Fig. 2. Chromosomes of parent and its F1 offspring, (a) parent, (b) and (c) cells of offspring and their representative karyotypes [Arrows for SAT- chromosomes].

Karyotype variation between roots of the same clove

The findings of variable karyotype formula in single cells showed significant difference between the mean values of total chromosome length (CL) and arm ratio (AR) of all 16 chromosomes at cells of three separated roots and consequently, among two separate cloves within the same bulb. This analysis was also performed between values of chromosome length and arm ratio of three bulbs of the studied clone) as shown in Tables 3 and 4.

\section{Chromosome length and arm ratio}

Means of chromosome lengths (CL) of the 16 chromosomes in (3 cells of each) of three roots in each of the six cloves derived from three bulbs of Egaseed 2 clone (two cloves in each bulb) are shown in Table 3. The variation in length of chromosomes is illustrated and represented graphically in Fig. 3. The mean values of chromosome length were significantly different between all examined roots of bulb 1 and also among the roots of one clove of both bulb 2 and bulb 3, while those of the other cloves of both bulb 2 and bulb 3 were insignificant. It means that about two thirds of cells of total examined roots and cloves exhibited significant differences in CL between them when compared separately. For instance, in the bulb 1, the CL of chromosomes numbered. 11, 12, 15 and 16 , showed significant differences between roots of clove 1 , while those of chromosomes numbered 1 , 2, 3, 13, 14 and 15 showed significant differences between roots of clove 2 . 


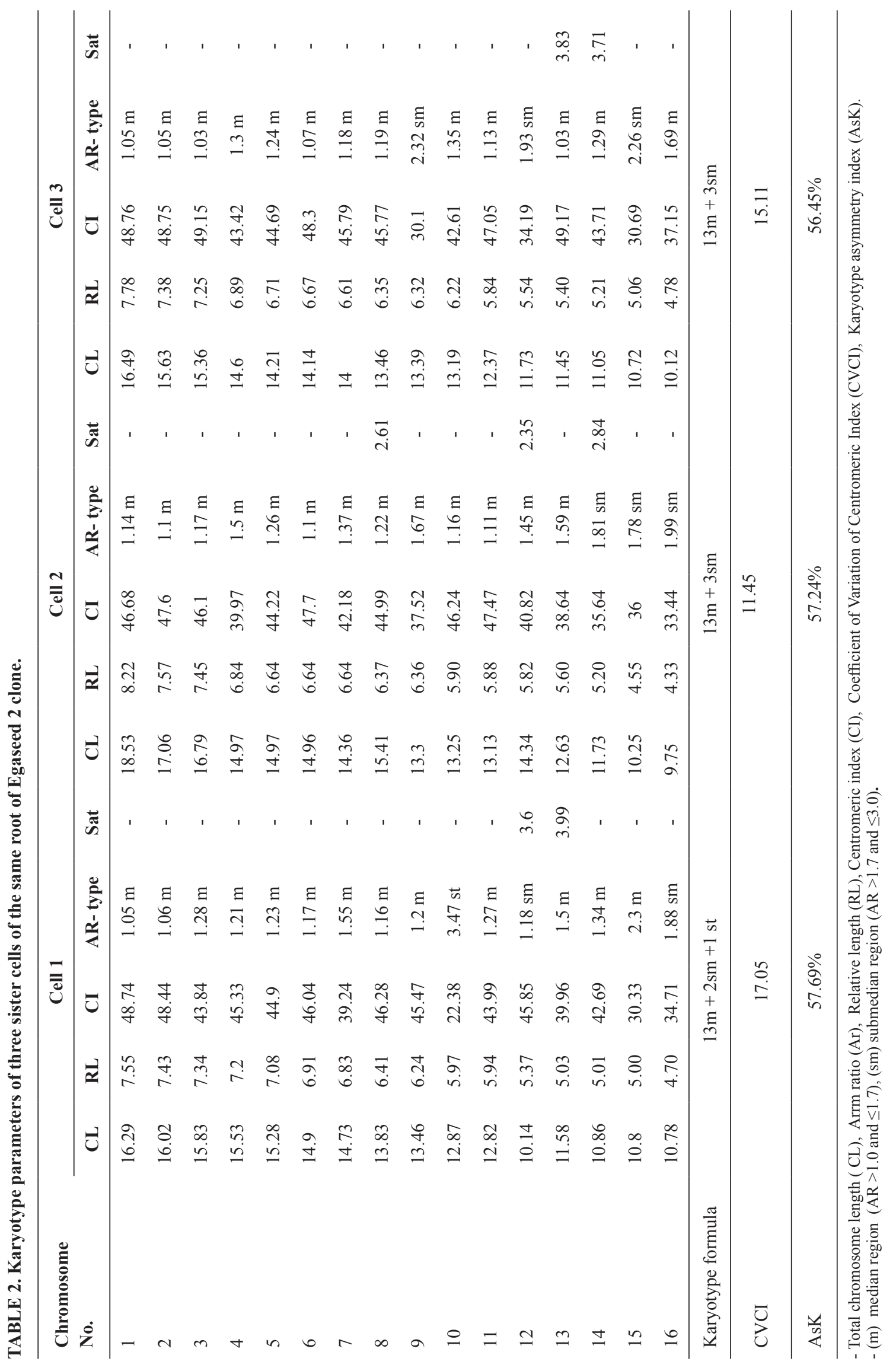

Egypt. J. Bot. 60, No.3 (2020) 


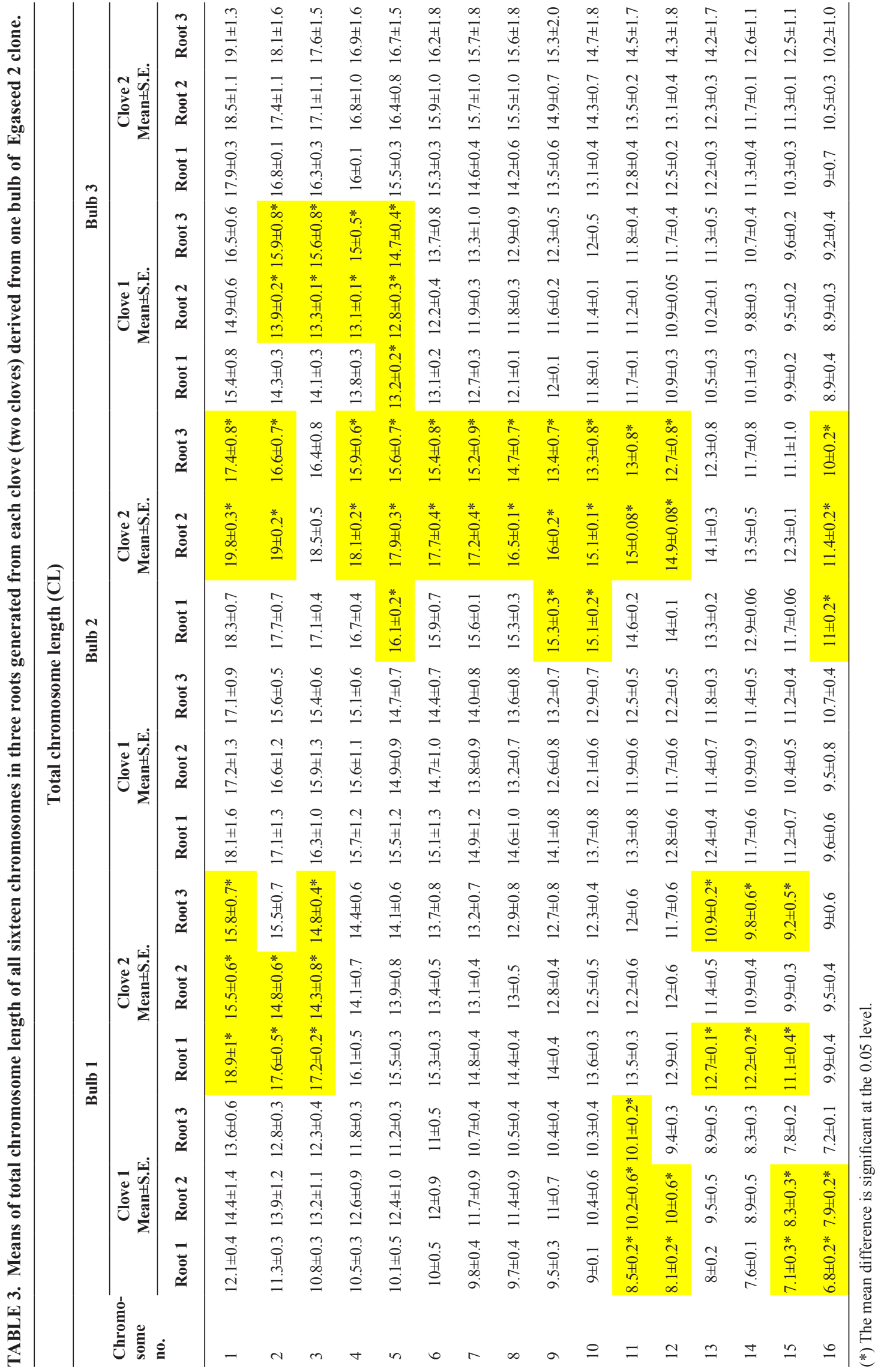

Egypt. J. Bot. 60 , No.3 (2020) 


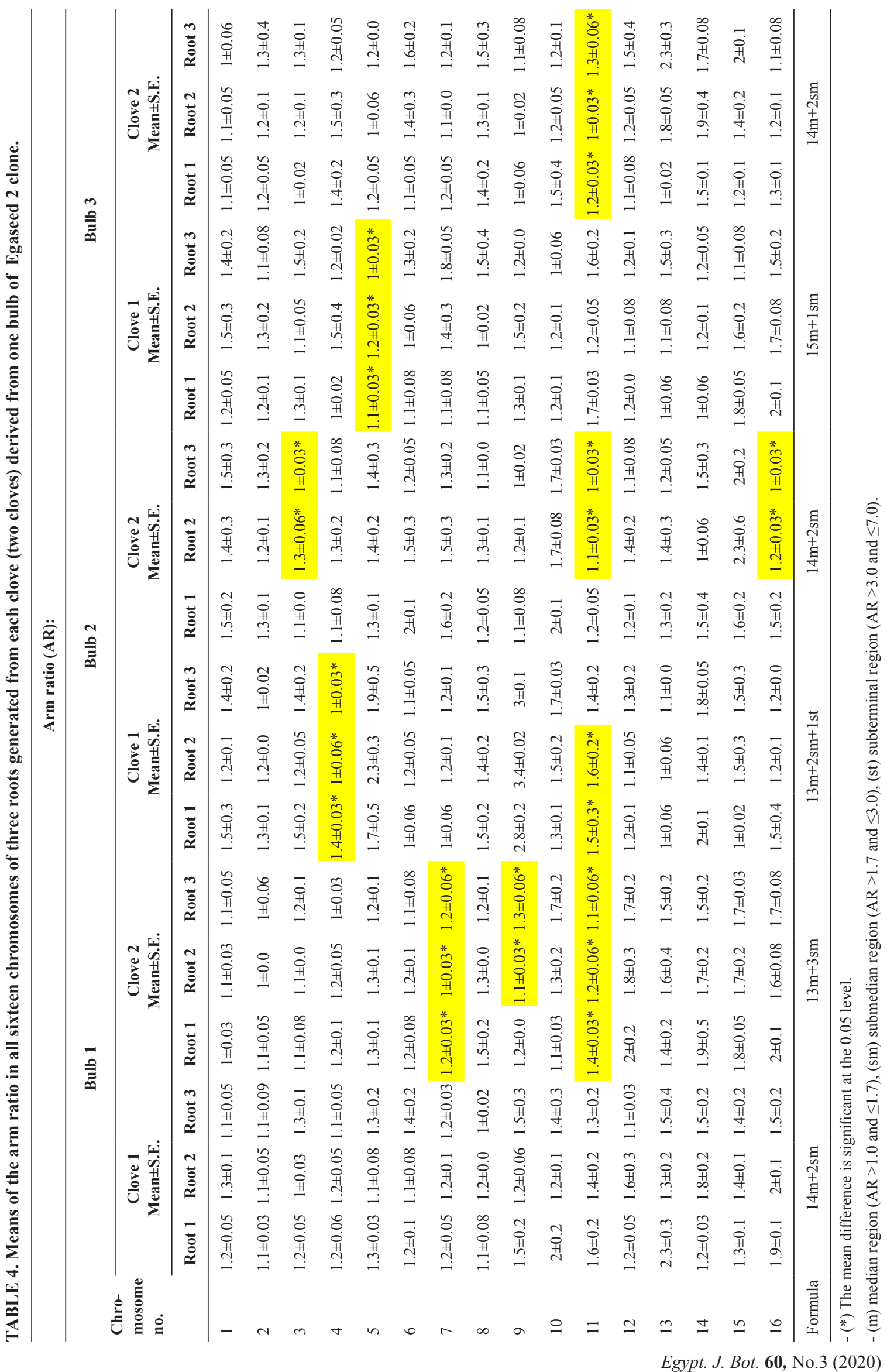




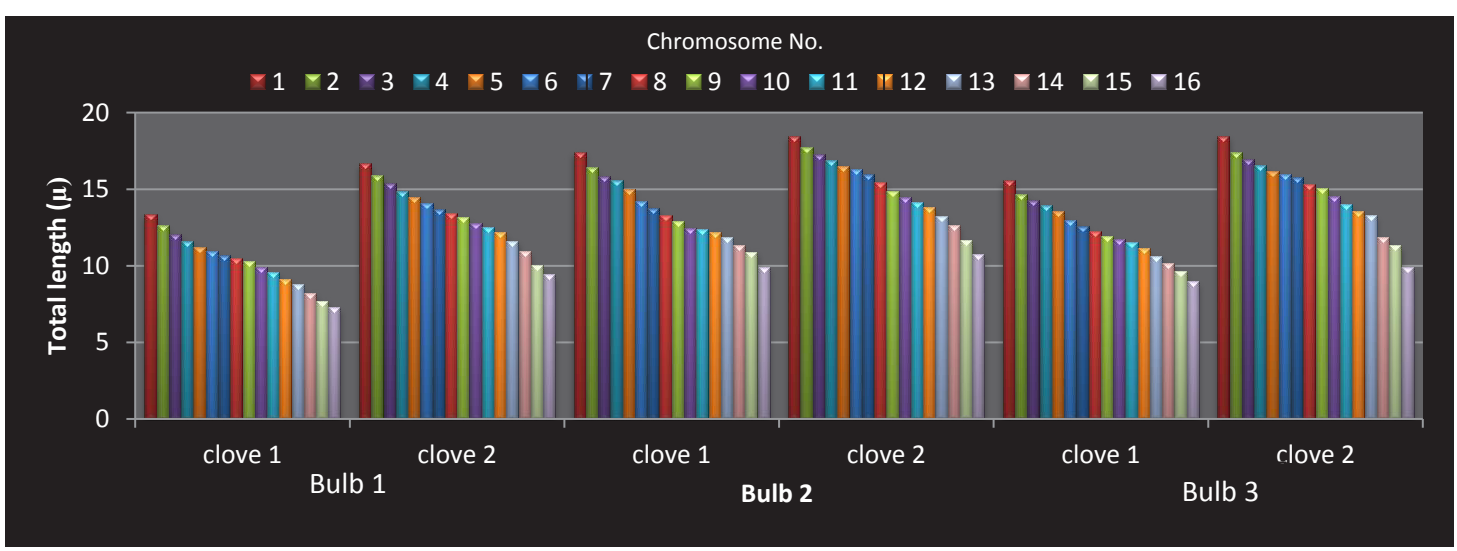

Fig. 3. Means of total chromosome length of all sixteen chromosomes in three roots generated from two cloves in each of three bulbs of Egaseed 2 clone.

Means of arm ratio (AR) of the 16 chromosomes in cells of three roots (3 cells of each) of the six cloves derived from three bulbs are given in Table 4. Insignificant differences of the arm ratio (AR) value were observed for the chromosomes in the examined roots of the clove 1 , while arm ratios of chromosomes numbered. 7, 9 and 11 showed significant differences between the roots of the clove 2 derived from the bulb 1 . In bulb 2, roots of clove 1 exhibited a significant difference in the arm ratios of chromosomes numbers 4 and 11, while those of chromosome numbered 3,11 and 16 showed significant differences between roots of clove 2. In bulb 3, a significant differences of the arm ratios were recorded in chromosome numbered 5 and 11 between the roots of cloves 1 and 2 , respectively as shown in Fig. 4 and detailed in Table 4. Consequently, observed differences has been observed in karyotype formula between cloves even they were derived from the same bulb as shown in Table 4.

\section{Relative length of chromosome and centromere index}

Data in Table 5 show the following chromosome criteria: RL, CI, CVCI and AsK (as percentages) and indicate difference between chromosome complements in roots. For example, chromosome numbered. 1 in bulb 1-clove 1 has a relative length value of $8.4 \%$ in root 1 while it was 7.7 and $7.9 \%$ in roots 2 and 3 respectively. Centromeric index vacillated from 43.6 to 44.6 and $42.5 \%$ in root 1,2 and 3 respectivly. In addition, Coefficient of Variation of Centromeric Index (CVCI) was $13.8,12.6$ and $11.8 \%$ in roots 1,2 and 3 respectively. Karyotype asymmetry index (AsK) was recorded as 57.43, 57.11 and 55.4 in root 1,2 and 3 , respectively.

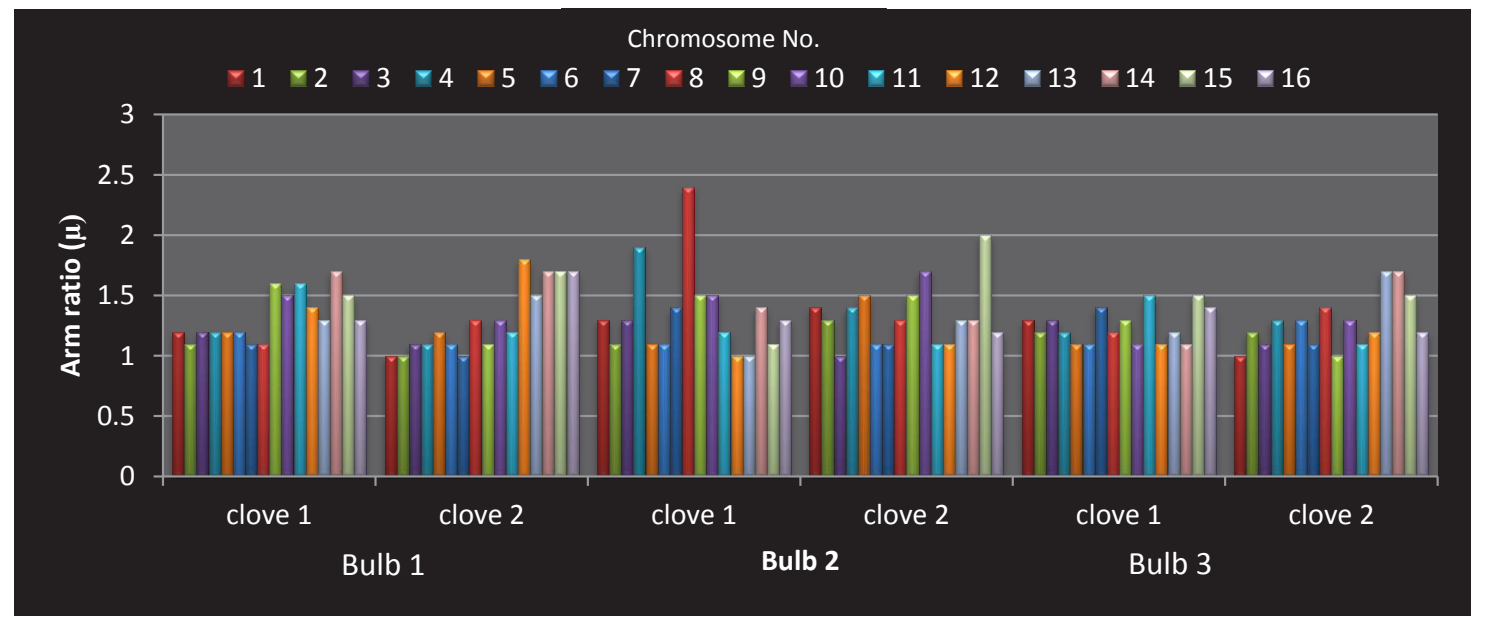

Fig. 4. Means of arm ratio of all sixteen chromosomes in three roots generated from two cloves in each of three bulbs of Egaseed 2 clone.

Egypt. J. Bot. 60 , No.3 (2020) 


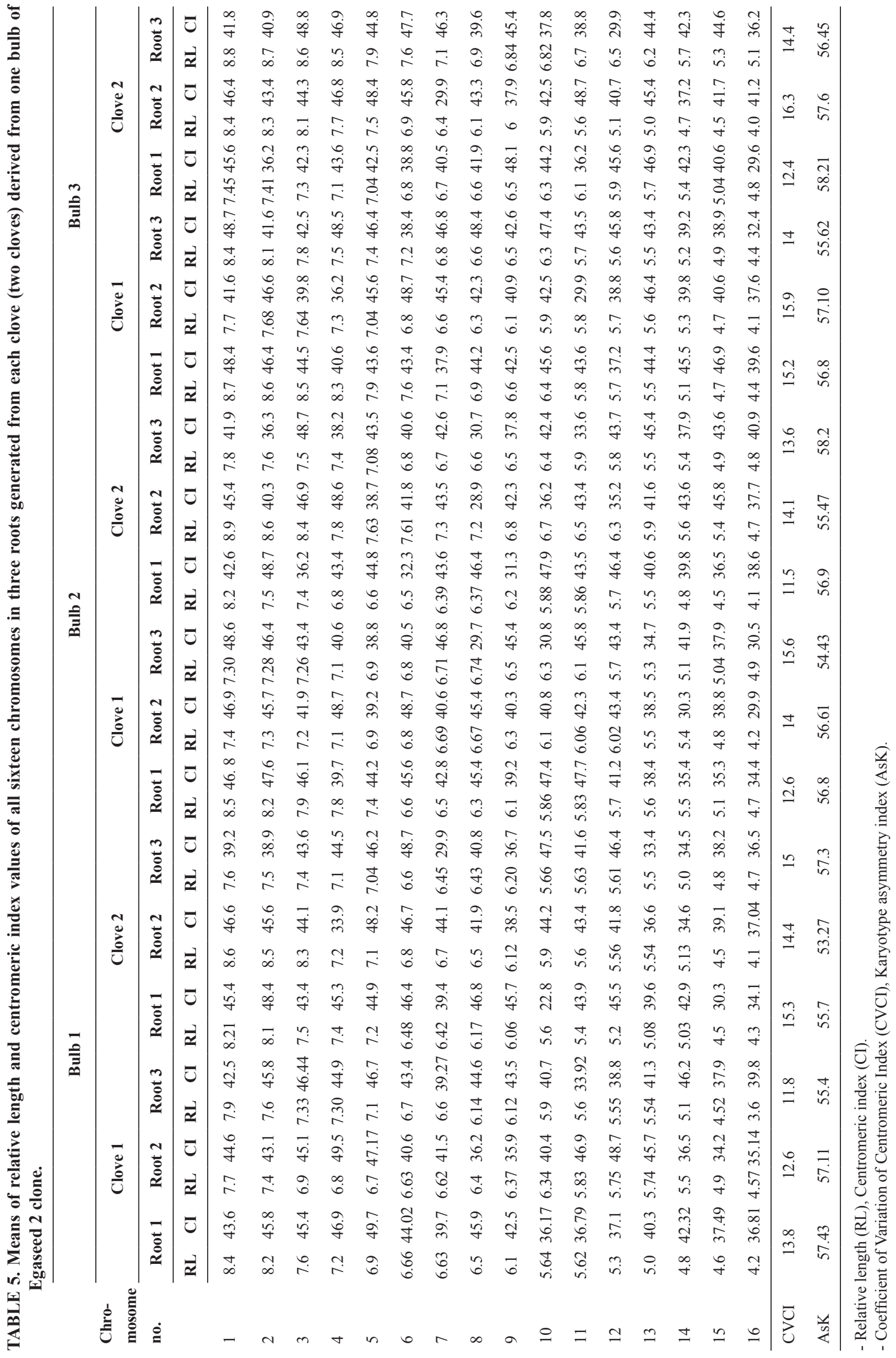

Egypt. J. Bot. 60, No.3 (2020) 
Karyotypic variation between parent cloves and their offspring

Data in Table 6 and Figs. 5, 6 displayed the means of chromosomal measurements which estimated from parental plant (clove) and its derivative filial plants (three cells in each root) and showing the transmitted vertical variation.

For parent cells, the karyotype formula was $(1 \mathrm{M}+13 \mathrm{~m}+2 \mathrm{sm})$, while those of filial progeny plants were markedly different $(13 \mathrm{~m}+3 \mathrm{sm})$ for roots no. 1, 3 and $(12 \mathrm{~m}+4 \mathrm{sm})$ for root no. 2 . Significant differences were also recorded in CL values of chromosome nos. 1, 7, 14 and 15 between the parent plant and its derivative offspring plants. The Arm ratios (AR) of chromosomes no. 4, 9, 14 and 15 were significantly different between the parent and their offspring. A noticed variation was observed in values of RL and CI between cells of the parent and its progeny. Microphotographs and their constructed Karyograms of a parent cell and its offspring cells are represented in Fig. 2.

\section{Satellite instability}

As represented in Table 7, the secondary constrictions and satellites clearly showed unstable positions along with the different chromosomes in cells of the tested clone (Egaseed 2 ). Change in satellite position was estimated in the term of percentage of satellite presence in each chromosome of the complement at the examined cells and calculated as number of satellites in each chromosome/ total no. of SAT chromosomes) X 100.

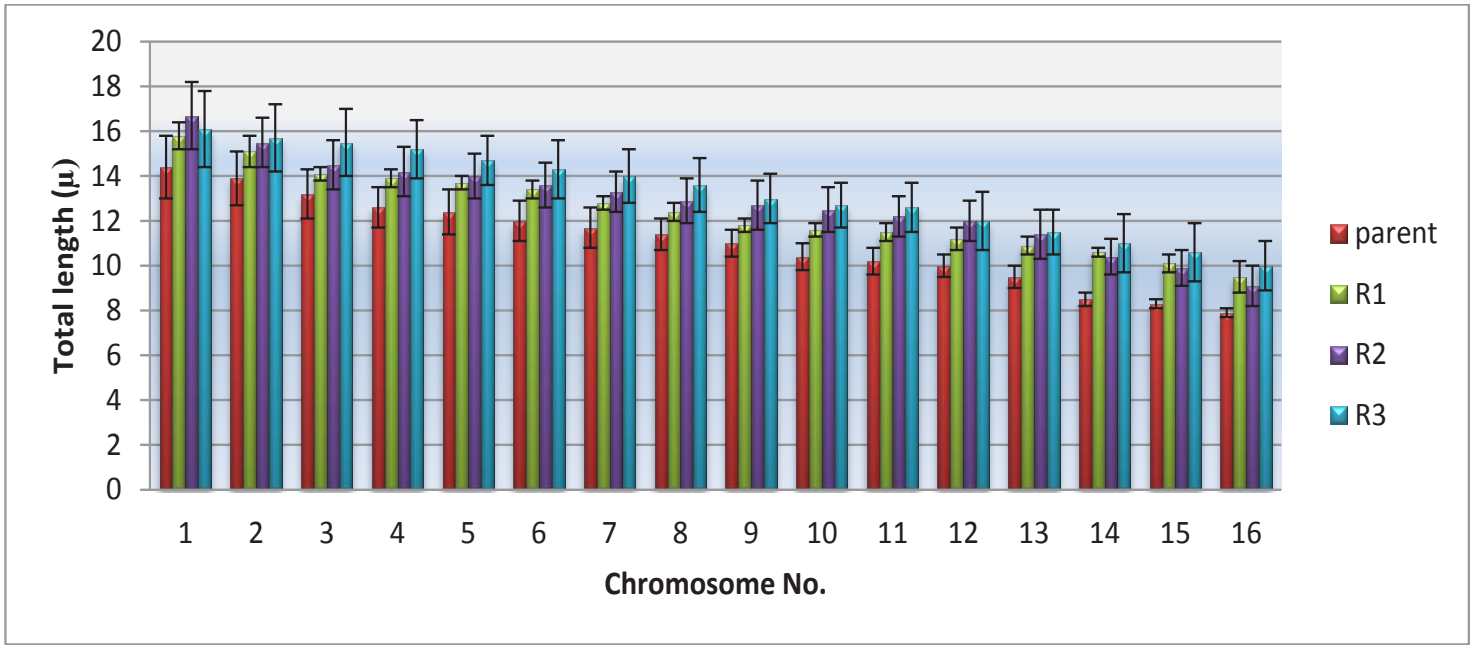

Fig. 5. Means of total chromosome length of all sixteen chromosomes in parent and its offspring (R1, R2 and R3).

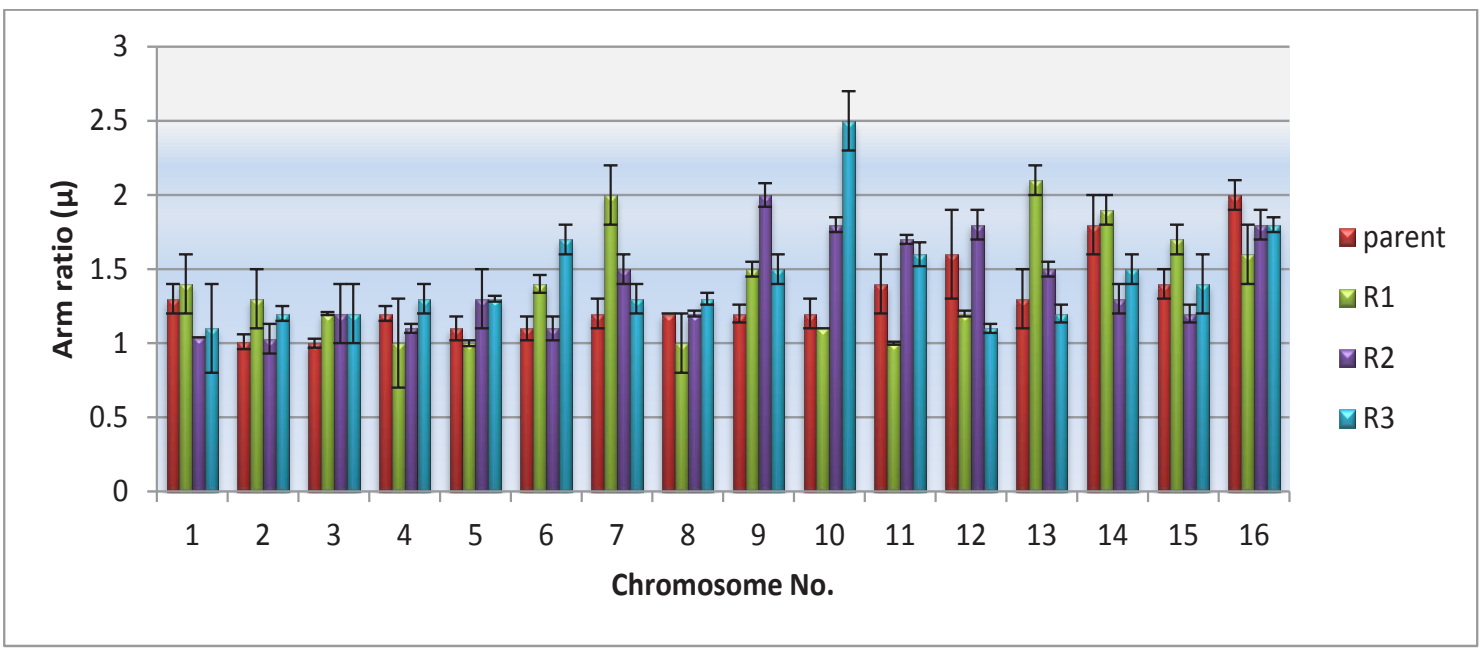

Fig. 6. Means of arm ratio values of all sixteen chromosomes in parent and its offspring (R1, R2 and R3).

Egypt. J. Bot. 60 , No.3 (2020) 


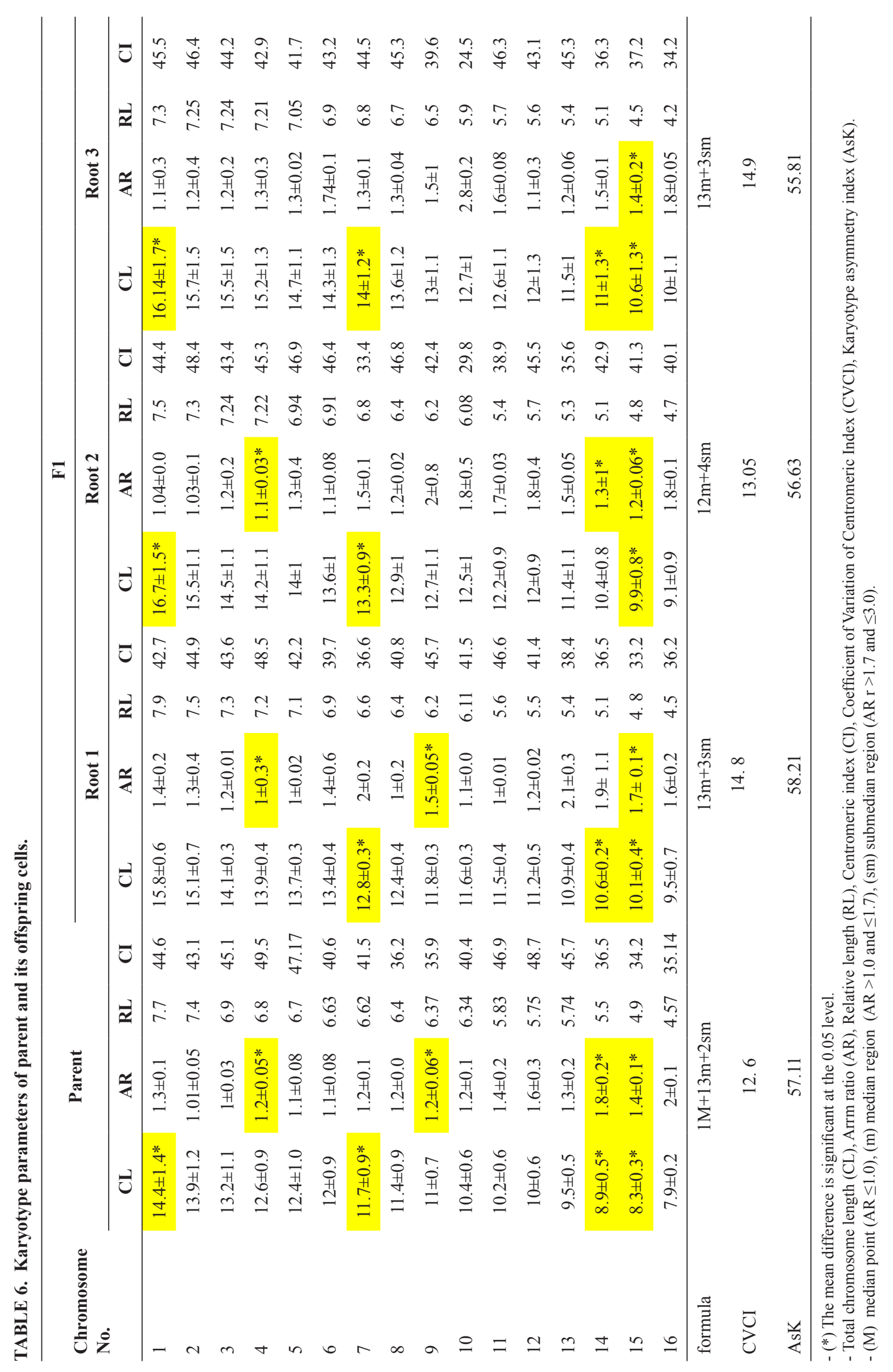

Egypt. J. Bot. 60, No.3 (2020) 


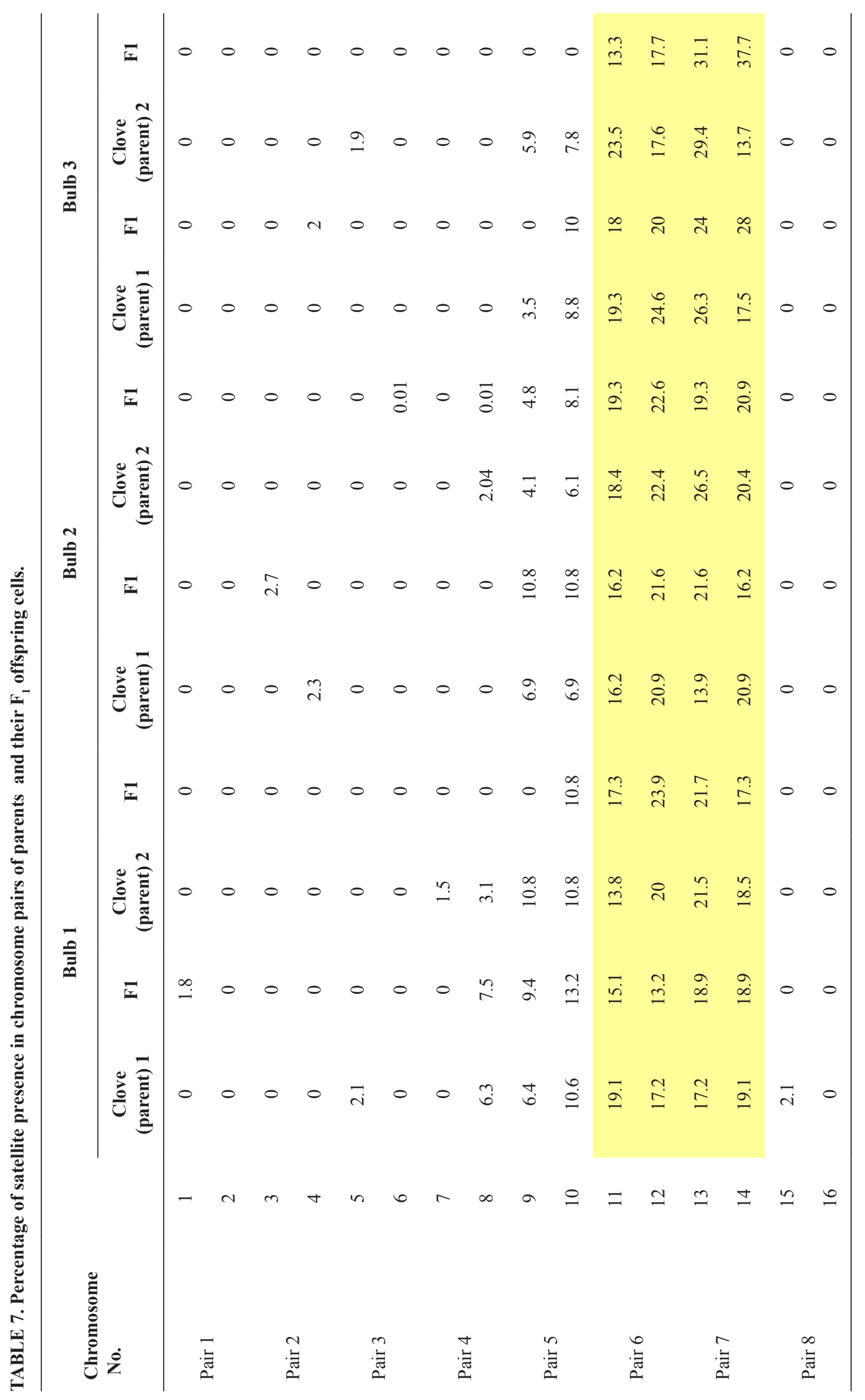

Egypt. J. Bot. 60 , No.3 (2020) 
Cells of three bulbs, two cloves in each bulb and roots from the progeny of each clove ( 20 good metaphase spread in each) were examined. As shown in Table 7 and Fig. 7, chromosome pairs numbered 6 and 7 were recognized as satellite bearing chromosomes with the highest percentage but there was a percentage of satellite presence in chromosome pairs no. 4 and 5 couldn't be neglected. For example, in bulb1, the percentage of satellite presence in chromosome pair numbered 5 was $17 \%$ and it was $36.3 \%$ in chromosome pairs numbered 6 and 7 in cells of parent 1 while it was $22.6 \%, 28.3 \%$ and $37.8 \%$ in chromosome pair numbered 5, 6 and 7 respectively in cells of F1 offspring. Also, data in table 7 showed variation in the appearance of the satellite on chromosomes of pairs numbered 4, 5, 6 and 7 in parent 2 and its offspring. In addition, satellite is visible on only one member of the pair as represented in karyotype ideograms (Figs. 1, 2). These results supported the previous one in this work which presented a notable difference in chromosome measurements between cells of even the same root in the studied clone of garlic which reflects the instability of its genome.

\section{Discussion}

Karyotype analysis has been widely conceded in plant phylogenetic and diversity studies for more than hundred years (Hong et al., 2000). Even with modern molecular techniques, karyotype is still a valuable source for taxonomy, phylogeny and diversity studies. The information like chromosome number, size and morphology has been of considerable value in understanding interrelations and delimitation of taxa (Stace, 2000; Karger \& Basel, 2008). The karyotype features have been frequently used for karyotype construction in Allium (Badr \& Ekington, 1977; Hamoud et al., 1990; Puizina \& Papeš, 1996; Fritsch et al., 2001; Altnordu et al., 2016). The measurements and evaluation of these features in the examined karyotypes showed variation particularly in total length of chromosomes, arm ratio, relative length and centromere index between the individual plants of the same garlic clone. Consequently, asymmetrical karyotypes have been recorded even in cells of the same root.

Chromosome complement of Egaseed 2 clone (bulk cells) was previously studied by Anwar \& Ata (2017) who reported 40 associations in $160 \mu \mathrm{m}$ of total genome length as measured by El-Mamlouk et al. (2002); Ata (2005); Ata \& Osman (2009) and Anwar (2011). It means that one association occurred per $3 \mu \mathrm{m}$ length. High frequency of associations may due to occurrence of different types of translocation. They also recorded the appearance of bridges and fragments at anaphase I indicated by paracentric inversions and/or reverse duplications as well as lagging chromosomes which may result from chromatin alterations and point gene mutations (Anwar \& Ata, 2017). These events resulted in more instable genome of garlic and interpreted the great variability of karyotypic configurations. For instance, in Italian garlic, Bozzini \& De Luca (1991) observed six acrocentric chromosomes, while Yüzbaşioğlu \& Unal (2004) reported that in Turkish garlic except sub-metacentric pair No.5, all chromosomes were metacentric. Different karyotypes were also suggested in several countries such as: India (Mukherjee \& Roy, 2012; Ramesh, 2015) and Egypt (El-Mamlouk et al., 2002; Ata, 2005; Osman et al., 2007; Mahmoud et al., 2017).

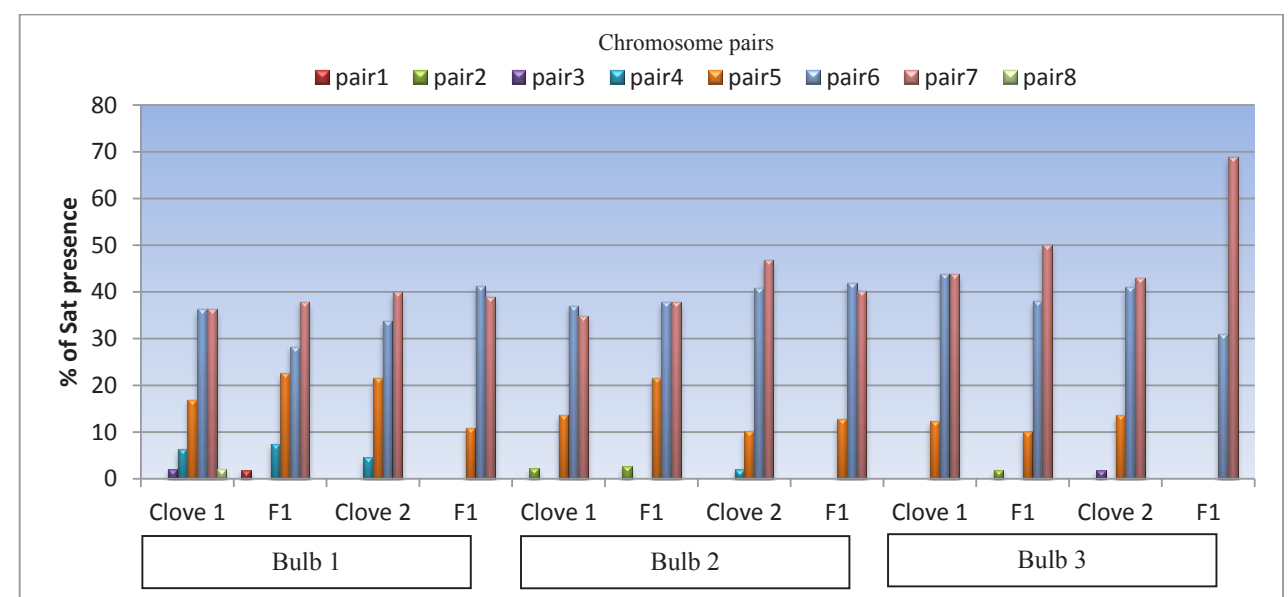

Fig. 7. Percentage of satellite presence in chromosome pairs of parents and their $F_{1}$ offspring cells. 
The architecture of chromosomes and their behavior are designed to adopt a proper strategy for the genetic improvement of plant species (Stace, 2000). Several researchers performed cytogenetic studies especially chromosome number and morphology at mitotic division as well as chromosomal association and behavior during meiotic division in the members of Liliaceae (Peruzzi et al., 2009; Mukherjee \& Ray, 2012), three species of Allium included some varieties (Ramesh, 2015) and A. sativum (Ata et al., 2010; Mahmoud et al., 2017). In agreement with these observations, the present data revealed a remarked difference in values of the coefficient of the variation for the centromeric index and consequently in karyotypic formula between sister cells of the same root and between the roots generated from the same clove as well as between cloves and their derivative filial roots.

Symmetrical karyotype is characterized by the predominance of $\mathrm{m}$ and sm chromosomes of approximately the same size. Increasing asymmetry may arise either through the shift of centromere position from median/submedian to terminal /sub-terminal or through the accumulation of alterations in the relative size between chromosomes of the complement (Zuo \& Yuan, 2011). However, the coefficient of the variation for the centromere index (CVCI) is a good measure of the relative variation in centromere index. The CVCI index has been cited in various cytological examinations to assess the karyotype differences (Chiarini \& Barboza, 2008; Martin et al., 2009; Peruzzi et al., 2009; Garc1'aBarriuso et al., 2010).

Several studies had reported difficulties in karyotype analysis of $A$. sativum. For instance, Osman et al. (2007) found frequent chromosomal breaks that may be responsible for the inability to mark karyotypes in A. Sativum. Other factors such as: i) high percentage of large fragments that misleads the karyotype making. ii) the great variation in satellite number and size among the studied genotypes in A. sativum (Awe \& Akpan, 2017). Differences in karyotype formula recorded between clones of $A$. sativum could be interpreted as results of frequent accumulation of somatic mutations under the apomictic nature of garlic (Ata et al., 2010; Mahmoud et al., 2017). Data in the present study showed that, variation in number and position of satellite chromosomes in the somatic complement of the examined cells is evident even within the same root. This result agree with Verma \& Mittal (1978) who reported that there was evidence of heterozygosity in both the nucleolar pairs numbered 6 and 7 suggesting structural alterations or rearrangements in these chromosomes of A. sativum.

Ramesh (2015) established the association of satellites with nucleolar organizers exclusively in the form of secondary constrictions represented by satellites in A. sativum like many other Allium species. Secondary constriction was present near the centromere of the short arm in the A. sativum. Verma \& Raina (1981) suggested that shifting of nucleolar organizer in the chromosome arm could be brought by deletion, unequal translocation or inversion . In the same point of study, Anwar \& Ata (2017) reported that, number of nucleolar chromosomes with constrictions in A. sativum (known as Sativum type) is still quiz. It has been reported that, number of satellite chromosomes are different among clones or varieties. They examined two flowering clones of garlic and found that the pollen mother cells (PMCs) exhibit different nucleoli attached to different chromosome pairs.

According to Maragheh et al. (2019), 35S rDNA sequences are located in the nucleolar organizer regions (NORs) of cultivated Allium species. The interspecies and intraspecific variation in the number and localization of rDNA sites has been attributed to various mechanisms such as transposon-mediated transposition events, a homologous and/or non-homologous unequal crossing over and gene conversion and chromosomal rearrangements, such as locus duplication/deletion (Raskina et al., 2008; Datson $\&$ Murray, 2006). In the current study, nuclear organizers and associated chromosomes appear to change position on different chromosomes in different roots of the same clove and in different cloves in the same plant.

Chromosomal changes like translocations and fusions could be responsible for rDNA movement in different chromosomes, triggering part of the variability documented. Moreover, the variability of the number and position of major rDNA loci could be caused by transposition mediated by transposons (TEs) and ectopic recombination (Cai et al., 2006; Datson \& Murray, 2006; Schmid et al., 2017; Ferretti et al., 2019). In this tendency, study of Helmey \& Anwar (2018) concerning the 
relationship between chromosomal changes and transposons activity which have been detected in Egaseed 2 clone of garlic by which it could be referenced as a reason for the diversions in chromosome measurements of the same garlic clone cells. Different molecular markers could be used to assess genetic diversity and confirm the molecular differences between the cloves derived from the same bulb which deduce the differing nature of garlic (Anwar et al., 2020).

\section{Conclusion}

Available data obtained herein revealed that, notable variations occur in the chromosome metrics of $A$ sativum, including chromosome length, arm ratios, centromeric index and consequently the karyotype formula indicating the existence of instable chromosome morphology even between individual sister cells in the same tissue. The results of this study, point out the need to undertake more extensive chromosome exploration to detect satellite and nucleolar regions movement and its impact on the karyotype and genome.

Acknowledgment: This work was done in Cytology lab., Department of Genetics, Faculty of Agriculture, Minia University. My sincere thanks to all members.

\section{Ethical approval: Not applicable.}

\section{References}

Altınordu, F., Peruzzi, L., Yu, Y., He, X. (2016) A tool for the analysis of chromosomes Karyotype. Taxon, 65(3), 586-592.

Anwar, G.M. (2011) Genetical and molecular studies on some garlic clones. Ph.D. Thesis, Faculty of Agriculture, Minia University, Egypt.

Anwar, G.M., Ata, A.M. (2017) Chromosome associations of two flowering garlic clones. Indian Journal of Plant Sciences, 6(2), 52-58.

Anwar, G.M., Mahmoud, M.A-H., Ata, A.M., Ragab, R.A-K., Bakry, H.S.H. (2020) Studies of Molecular Variation Sources Using RAPD and SSR Markers in Two Garlic Clones. Journal of Modern Research, 2, 115-122.

Ata, A.M. (2005) Constitutive heterochromatin diversification of two Allium species cultivated in Egypt. El-Minia Journal of Agricultural Research and Development, 25, 663-676.

Ata, A.M., Osman, S.A. (2009) Gametogenesis of two garlic clones selected from Egyptian indigenous forms. African Crop Science Conference Proceedings, 9, 483-487.

Ata, A.M., Mahmoud, M.A-H., Ragab, R.A-K.; Hanaa S.H. (2010) Chromosomal Studies on Egyptian Garlic during Tissue Culture Course. $2^{\text {nd }}$ Minia Conference of Agriculture and Environment, 2, pp. 437-445.

Awe, E.T., Akpan, U.U. (2017) Cytological study of Allium cepa and Allium sativum. Acta Satech, 9(1), 113-120.

Badr, A., Elkington, T.T. (1977) Variation of giemsa C-band and fluorochromes banded karyotypes and relationships in Allium subgenus Molium. Plant Systematics and Evolution, 128, 23-35.

Battaglia, E. (1963) Mutazione chromosomica e cariotipe fondamentale in Allium sativum L. Caryologia, 26, 1-46.

Bozzini, A., De Luca, P. (1991) Discovery of an Italian fertile tetraploid line of garlic. Economic Botany, 45(3), 436-438.

Cai, Q., Zhang, D.M., Liu, Z.L., Wang, X.R. (2006) Chromosomal localization of $5 \mathrm{~S}$ and $18 \mathrm{~S}$ rDNA in five species of subgenus Strobus and their implications for genome evolution of Pinus. Annals of Botany, 97, 715-722.

Chiarini, F.E., Barboza, G.E. (2008) Karyological studies in Jaborosa (Solanaceae). Botanical Journal of the Linnean Society, 156, 467-478.

Datson, P., Murray, B.G. (2006) Ribosomal DNA locus evolution in Nemesia: transposition rather than structural rearrangement as the key mechanism? Chromosome Research, 14, 845-857.

El-Mamlouk, E.A-K., Ata, A.M., Mahmoud, M.A-H., Foly, H., Allam, H.Z. (2002) Cytological features and isozymes profile of some Allium sativum (garlic) genotypes cultivated in Egypt. Minia Journal of Agricultural Research and Development, 22, 1420-1440. 
Etoh, T. (1984) Hybrids between wild garlic (Allium longicuspis Regel) and garlic (A. sativum L.). Proceedings of the Eucarpia $3^{\text {rd }}$ Allium Symposium, IVT, Wagenigen, The Netherlands, pp. 78-82.

Etoh, T. (1985) Studies on the sterility in garlic, Allium sativum L. Memoirs of the Faculty of Agriculture, Kagoshima University, 21, 77-132.

Ferretti, A.B.S.M., Ruiz-Ruano, F.J., Milani, D., Loreto, V., Martí, D.A., Ramos, E., Martins, C., Cabral-de-Mello, D.C. (2019) How dynamic could be the $45 \mathrm{~S}$ rDNA cistron? An intriguing variability in a grasshopper species revealed by integration of chromosomal and genomic data. Chromosoma, 128, 165-175.

Fritsch, R.M., Matin, F., Klass, M. (2001) Allium vavilovii $\mathrm{M}$. Popov et Vved. and a new Iranian species are the closest among the known relatives of the common onion A. cepa L. (Alliaceae). Genetic Resources and Crop Evolution, 48, 401-408.

Fritsch, R.M., Blattner, F.R., Gurushidze, M. (2010) New classification of Allium L. subg. Melanocrommyum (Webb \&amp; Berthel.) Rouy (Alliaceae) based on molecular and morphological characters. Phyton, 49, 145-220.

Garci'a-Barriuso, M., Bernardos, S., Amich, F. (2010) Chromosomal evolution in Mediterranean species of Ophrys sect. Pseudophrys (Orchidaceae): An analysis of karyotypes and polyploidy. Taxon, 59, 525-537.

Hamoud, M.A., Badr, A., Turki, Z. (1990) Cytotaxonomic relationships of some taxa of Egyptian Allium L. Cytologia, 55, 161-167.

Helmey, R.K., Anwar, G.M. (2018) Chromosomal aberrations and Ac/Ds transposition in Garlic. Chromosome Botany, 12(4), 72-76.

Hong, C.J., Wattanabe, H., Etoh, T., Iwai, S. (2000) Morphological and karyological comparison of garlic clones between the center of origin and westernmost area of distribution. Memoirs of the Faculty of Agriculture, Kagoshima University, 36, $1-10$.

Karger, S., Basel, A.G. (2008) Chromosome numbers in plant cytotaxonomy: concepts and implication. Cytogenetic and Genome Research, 120, 339-350.
Khoshoo, T.N., Atal, C.K., Sharma, V.B. (1960) Cytotaxonomical and chemical investigations on the north-west Indian garlics. Research Bulletin of the Panjab University, 11, 37-47.

Koul, A.K., Gohil, R.N. (1970) Cytology of the tetraploid Allium ampeloprasum with chiasma localization. Chromosoma, 29, 12-19.

Levan, A. (1932) Cytological studies in Allium: II. Chromosome morphological contribution. Hereditas, 16, 257-294.

Levan, A. (1935) Cytological studies in Allium: IV. The chromosome morphology of some diploid species of Allium. Hereditas, 20, 289-330.

Mahmoud, M.A-H., Ata, A.M., Anwar, G.M., Tawfeek, A-R., Dakhly, O.F. (2017) Studies of some cytological features of garlic (Alliium sativum L.) clones cultivated in Egypt. Egyptian Journal of Plant Breeding, 21(5), 800-819.

Maragheh, F.P., Janus, D., Senderowicz, M., Haliloglu, K., Kolano, B. (2019) Karyotype analysis of eight cultivated Allium species. Journal of Applied Genetics, 60, 1-11.

Martin, E., Dinc, M., Duran, A. (2009) Karyomorphological study of eight Centaurea L. taxa (Asteraceae) from Turkey. Turkish Journal of Botany, 33, 97-104.

Mukherjee, A., Ray, S.C. (2012) Karyotype analysis of five species of Allium. Indian Journal of Fundamental and Applied Life Science, 2, 374-383.

Osman, S.A.M., Ata, A.M., Gad El-Hak, S.E. (2007) Morphological germination bolting and cytogenetical characteristics of fourteen promising garlic genotypes. African Crop Science Conference Proceedings, 8, 2005-2012.

Peruzzi, L., Leitch, I.J., Caparelli, K.F. (2009) Chromosome diversity and evolution in Liliaceae. Annals of Botany, 103, 459-475.

Puizina, J., Papeš, D. (1996) Cytogenetical evidences for hybrid structure and origin of diploid and triploid shallots (Allium cepa var. viviparum, Liliaceae) from Dalmatia (Croatia). Plant Systematics and Evolution, 199, 203-215.

Ramesh, A. (2015) Karyotypic analysis in three species 
of Allium and their some Varieties. International Research Journal of Biological Sciences, 4(9), 1-9.

Raskina, O., Barber, J.C., Nevo, E., Belyayev, A. (2008) Repetitive DNA and chromosomal rearrangements: speciation-related events in plant genomes. Cytogenetic and Genome Research, 120(3-4), 351-7.

Sato, Y., Izumiya, K., Sato, H., Cowell, J.L., Manclark, C.R. (1980) Aerosol infection of mice with Bordetella pertussis. Infection and Immunity, 29, 261-266.

Schmid, M., Steinlein, C., Feichtinger, W., Nanda, I. (2017) Chromosome banding in amphibia. XXXV. Highly mobile nucleolus organizing regions in Craugastor fitzingeri (Anura, Craugastoridae). Cytogenetic and Genome Research, 152, 180-193.

Stace, C.A. (2000) Cytology and cytogenetics as a fundamental taxonomic resource for the $20^{\text {th }}$ and $21^{\text {st }}$ centuries. Taxon, 49, 451-477.

Verma, R.C., Raina, S.N. (1981) Cytogenetics of Crotalaria II. Male meiosis in 8 species of Crotalaria. Cytologia, 45, 297-306.

Verma, S.C., Mittal, R.K. (1978) Chromosome variation in the common garlic, Allium sativum L. Cytologia, 43, 383-396

Yüzbaşioğlu, D., Unal, F. (2004) Karyotyping, c- and NOR banding of Allium sativum L, (liliaceae) cultivated in turkeyTurkey. Pakistan Journal of Botany, 36(2), 343-3491.

Zuo, L., Yuan, Q. (2011) The difference between the heterogeneity of the centromeric index and intrachromosomal asymmetry. Plant Systematics and Evolution, 297, 141-145.

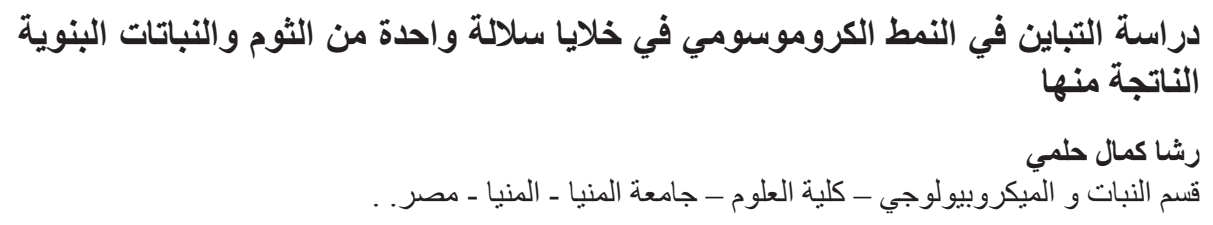

يتكاثر الثوم (Allium sativum L.) خضريا، لذلك فإن الطفرات الجسدية هي المصدر الوحيد للتباين

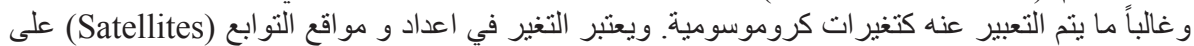

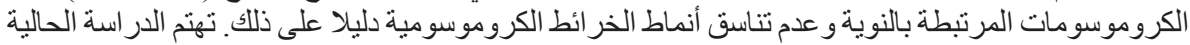

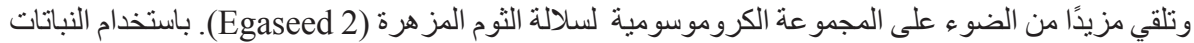

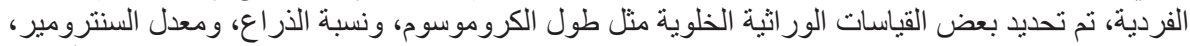

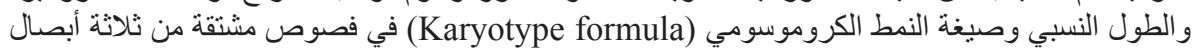

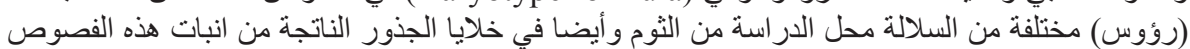

.(filial plants)

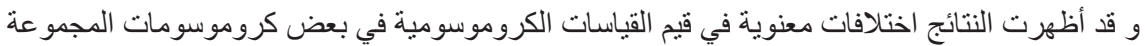

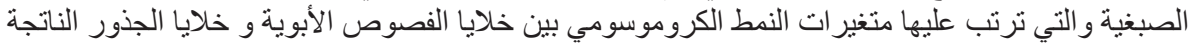

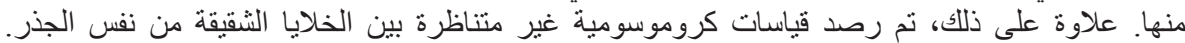

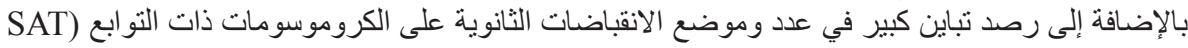
(chromosome للخلايا التي تم فحصها. 